\section{He wants your opinion}

IT has been a busy week for Lord Crowther-Hunt, Minister for Higher Education at the Department of Education and Science, who has delivered three major speeches on the subject of priorities within the highereducation sector. These, coupled with Mr Prentice's recent appearance before a House of Commons Select Committee, go some way towards reassuring those in higher education that the department, which has kept a distinctly low profile in this field for a long time, has not forgotten about them entirely. And the generally thoughtful nature of these contributions, positively inviting dialogue, deserves an intelligent response from the intellectual community and from employers.

The problem confronting educational planners is this. At present there are about 460,000 full-time students in universities and in polytechnics and colleges in England and Wales. There is still a commitment to raise this figure to 640,000 by 1981 . But this sort of expansion could not be carried out against a background of economic stagnation unless the government were to devote what growth money it had to higher education, to the detriment of schools, hospitals and so on. This it clearly will not do; Lord Crowther-Hunt does at least go through the motions of musing whether there is a strong relationship between investment in higher education and long term economic growth, but concludes only that "it would be asking too much for a reasonable man to believe that a higher quality labour force does not have a higher potential than a lower quality one, while recognising at the same time that quality in this context has many dimensions". Hardly a strong case for Mr Prentice to argue in Cabinet for preferential treatment for higher education to get us out of our economic hole. Thus the recent Budget cuts of $£ 1,000$ million in public expenditure planned for $1976 / 7$ mean substantial cuts in education and science, and instead of a growth rate of $2.7 \%$ in that year, there will only be room for about $1 \%$ more.

Inevitably, one must then ask whether expansion to 640,000 makes sense, and if it does, what sort of education this means for the swollen numbers. The answer to the first question is almost certainly that the target will not be reached, although obviously the government would like not to have to be responsible for taking that decision itself; it may well be let off the hook by the continuation of the trend amongst the young to forego higher education voluntarily. But even if targets are lowered, it is inescapable that the atmosphere within the higher education world will have to change. Lord CrowtherHunt dropped several hints of things to come:

Student/staff ratios are bound to rise from their present value in universities of $8.4: 1$. A figure of $10: 1$ or even $11: 1$ was mentioned-from which it could be inferred that present staffs would spend more time teaching, rather than that new staff would be recruited.
- Manpower planning will be conducted in an attempt to respond to the perceived future needs of employers.

- Efforts will be made to make courses more relevant to the needs of the country.

Universities and polytechnics will be urged to collaborate more.

The balance between teaching and research will have to be looked at.

Some of this can be welcomed, particularly any efforts within the manpower planning field to understand how the young decide what to study - and whether they are open to persuasion to change their mind. The worry must always be whether the planners' crystal balls perform any better than randomly in predicting needs five or ten years hence. Any positive intervention at present would presumably be devoted to restocking chemistry, and to a lesser extent, physics departments; it would be unlikely to be urging yet more students to think of medicine as a career. Yet how much confidence can we really have that by responding to present imbalances we shall create future prosperity? Maybe the chemical industry would profit more from an influx of mathematicians and the medically-trained than by continuous recruitment of chemists, and maybe this is unknowable before the fact.

Similar concern must also be expressed that 'relevance to the nation's needs' can be pushed much further without producing dreary courses of study away from which bright students will flee. Lord Crowther-Hunt's contribution to the debate here is less than worthy- "many educationists will disagree [with relevance] but they are surely going to find it very difficult indeed to argue for the contrary principle, namely 'irrelevance'". Many besides educationists will find such stark categorisation unhelpful. The contrary principle to which many devote their teaching career is intellectual agility and flexibility and is surely as much to be sought after now as ever.

There has as yet been scarcely a murmur from the academic community at the increase in productivity called for if student/staff ratios are to rise. But there is one quite serious problem which deserves early airing. The higher education world is not like some vast nineteenth-century construction industry where the foreman/ navvy ratio could be juggled at will by hiring and firing. For better or worse almost all staff have tenure. Further, staff tend to come in thousands of little cells called departments, each with its own proud independence. A smooth change in student/staff ratio at the macroscopic level can produce some hideous anomalies at the microscopic level.

Lord Crowther-Hunt has done the higher-education community a service by giving early public notice of change. The community can help mould its future by an intelligent response. 